\title{
Obituary
}

\section{Professor E. H. S. Simmonds}

\section{$1919-1994$}

Stuart Simmonds spent the whole of his academic career at the School of Oriental and African Studies, from his appointment to a lectureship in linguistics in 1948 until his retirement, as Professor of the Languages and Literatures of South East Asia, in 1982. In the early part of that career he was responsible for establishing, almost single-handedly, the study of Tai languages and literatures, and by extension, of Thailand itself, in this country. He devoted immense energies to that task, which involved far more than the provision of new courses in language and literature, in themselves major commitments, not least in his supervision of a large number of research students from Thailand who came to work with him on a wide range of literature topics. Within the School he also took on a heavy administrative burden, notably as Head of the Department of the Languages and Cultures of South East Asia and the Islands from 1966 until his retirement, from which position he ensured that command of language, and the sensitivity to culture which that brought, occupied a central place in the study of the region, whatever the discipline. Outside the School he worked to promote a greater awareness and understanding of Thailand, notably through public lectures on a wide spread of subjects, from aspects of Thai culture to current political developments in the region. And, of course, for many years he played a major role in the affairs of the Royal Asiatic Society. He became a Fellow in 1954, and was first elected to the Council in 1962: he served continuously on the Council for the next twenty-two years. He was Director, $1965-8$, and a Vice-President in $1968-72$ and again in $1976-80$. He was President of the Society, I973-6. In addition, he edited, with Mr S. E. Digby, the Society's Sesquicentenary volume, The Royal Asiatic Society. Its History and Treasures (1979). Stuart Simmonds's unique contribution to the study of Tai languages and literatures, and to the development of Thai studies in general, was formally recognized in 1988 when the King of Thailand appointed him Commander of the Most Exalted Order of the White Elephant.

His introduction to South East Asia, and to Thailand in particular, had been a brutal one. Commissioned in 1940 , he had been involved in the Malayan campaign which ended with the surrender of Singapore to the Japanese on is February I941. He had then spent four years as a prisoner-of-war, initially in Singapore and then in the Thai camps, close to the Burma border. That experience profoundly shaped the rest of his life. From it came a deep understanding of the tenuous nature of human existence, a natural sympathy for the frailty and failings of others, and an extraordinary capacity to see hope and goodness in even the most distressing conditions. And, of course, it introduced him to Thailand, to the Thais and to Thai. Many years later, facing a student who had been far from diligent in learning the Thai numerals, he could recount that he had mastered them by observing the mile-stones as 
he had been marched from Bangkok to the camps in the carly I940s. The rebuke was gently delivered.

In fact it would have been against his character to have delivered a rebuke in any other way. Above all, he had a generosity of spirit which few can match, and which all those who knew him will never forget.

IAN BROWN 